UDC 539.3

\title{
FATIGUE CRACK GROWTH IN ALUMINUM ALLOY FROM COLD EXPANDED HOLE WITH PREEXISTING CRACK
}

\author{
Petro Yasniy ${ }^{1}$; Oleksandr Dyvdyk ${ }^{1}$; Oleksander Semenets ${ }^{2}$; \\ Volodymyr Iasnii ${ }^{1}$; Andrii Antonov ${ }^{1}$
}

\author{
${ }^{1}$ Ternopil Ivan Puluj National Technical University, Ternopil, Ukraine \\ ${ }^{2}$ Company Antonov, Kiev, Ukraine
}

\begin{abstract}
Summary. The fatigue life of aircraft structure elements with operational damage in the vicinity of the hole was investigated. The plates $60 \mathrm{~mm}$ wide and $6 \mathrm{~mm}$ thick made of D16chT aluminum alloy with a central hole were taken for the study. Fatigue damage was examined with an corner quarter-elliptical fatigue crack with a length of 1,25 mm, which was initiated from an edge notch of 0,5 $\times 0,5 \mathrm{~mm}$. The fatigue crack growth rate on the surface of the plate after mandrel hole with cold expansion degree $i=2,7 \%$ increases up to 15 times and residual lifetime in three times compared to the virgin plate.

Key words: cold expansion hole, preexisting crack, stress intensity factor, residual lifetime, plate with hole, fatigue crack growth, aluminum alloy.
\end{abstract}

https://doi.org/10.33108/visnyk_tntu2020.03.005

Received 21.08.2020

Statement of the problem. Generally, there are two approaches to design fatigue life of aircraft structure elements in aircraft industry: one is based on the criterion of the ultimate limit state and the serviceability limit. Operators seek to extend the life of an aircraft, once it has reached its design life. Programs to extend the design life are elaborated to determine what type of maintenance and repair works are required for further safe operation of aircrafts. Once structure design life has been reached, the greatest number of cracks are found by nondestructive testing methods near the fastener holes, which are stress concentrators. One of the promising methods for increasing the residual durability of service damaged parts within the vicinity of holes is cold expansion technique. When reasoning the efficiency of such technology, it is necessary to study its influence on further fatigue crack growth, as well as improve methods for simulation of the crack growth and evaluation of residual durability taking into account residual compressive stresses within the vicinity of a hole and crack apex, size and geometry of service damage.

Analysis of research. In some cases, the existing technological methods of processing are also an effective means for increasing the fatigue life of structural elements with service damage in the vicinity of the fastener holes. Most of them deals with machining of structure elements in the area of holes by means of plastic deformation of material layer. In particular, Ball and Lowry [1] found that for wing root part of a Fighter aircraft the residual life of aluminum plates with angled cracks adjacent to fastener hole is increased 10-15 times after being mandrelled under constant load amplitude and 2-4 times under spectral load.

Influence patterns of cold expansion strain for aluminum and steel plates with fatigue damages within the vicinity of hole and their impact on crack growth are investigated as well as initial length of angular crack with the size that can be adequately detected by methods of nondestructive inspection [2]. Experimental investigations, FEM simulation showed considerable influence of cold expansion direction on distribution of residual stresses through 
the thickness of plates and inadequate simulation of the uniform hole expansion [3, 4]. Various technological methods are employed to strengthen the holes by cold plastic deformation: drawing through the balls or tapered mandrels with calibration zones [5-7], split sleeve technique $9[8,9]$ and barrier crimping. Also, with an advent of new alloys in $1960 \mathrm{~s}$, techniques of hole cold expansion using the memory alloy tools were later developed and patented [10, 11]. Detailed review of hole cold expansion techniques of the late 2 decades, which depicts their advantages, disadvantages and limitations, can be found in the work [12]. Among the promising techniques of cold expansion one should distinguish double cold expansion [13] and combination of cold expansion with friction stir processing due to additional rotation of the tool [14], combination of hole cold expansion and further ultrasound techniques, which are applied to bridge steel structures [15] and considering the impact of rivet hole interference on stress-strain state, cold expansion efficiency and fatigue life of rivet assemblies in aircraft structures [16]. In the article [17] the calculating estimation of fatigue damage and stress-strain state under the cyclic loading using the ultimate exhaustion of cyclic plasticity and analysis of stress intensity factors (SIF) for semi-elliptical surface cracks in low-alloy steel using the finite element method was conducted [18].

Objective. Elaboration of methods and study of the impact of cold expansion hole on fatigue crack growth and residual life of an aircraft load-carrying structure elements with operational damages within the zone of fastener holes.

Experimental techniques. Fatigue crack growth was investigated on D16chT aluminum alloy plates with a central hole under constant amplitude loading (Fig. $1 \mathrm{a}$ ). Dimensions of aluminum alloy specimens: width of working area $-60 \mathrm{~mm}$; length $-120 \mathrm{~mm}$; thickness $-6 \mathrm{~mm}$ (Fig. 1 a). Crack length $c$ (on the specimen surface) and $a$ (through-cracked specimen) are shown on Fig. $1 \mathrm{~b}$, through crack growth with the length $c$ and $c_{1}$ on the surface is also shown (Fig. 1 c).

Two types of specimens were used to investigate the impact of cold expansion on fatigue crack growth rate. First type is the specimen with a central hole and a pre-crack of the corner notch which is perpendicular to the direction of drawing and subjected to cold expansion. The second type is the specimen with a central hole and a pre-crack of the corner notch which is perpendicular to the direction of drawing. In the second case all technological operations were the same as in the first one apart from the process of cold expansion. Specimen preparation technology for testing the cold expanded and non-cold expanded samples for fatigue crack growth resistance is shown in table 1.

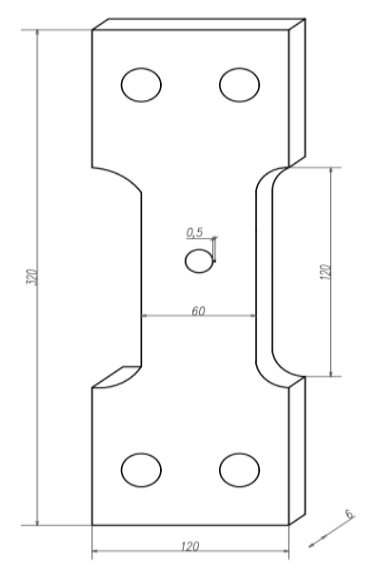

a)

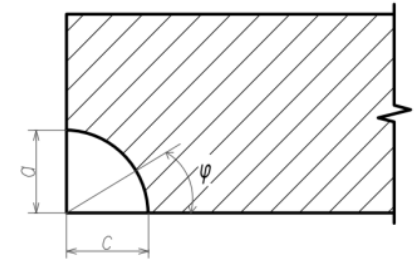

b)

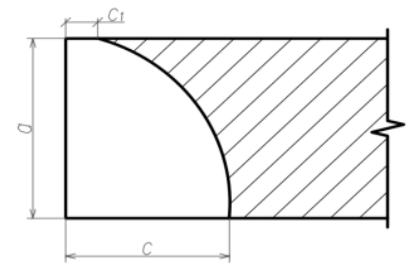

c)

Figure 1. Specimens for the investigation of fatigue: a - drawings of specimens b, c - is the crack propagation pattern ( $a$ - is the crack length through the surface of the hole; $c$ - is the crack length on the surface; $c_{1}-$ is the crack length on the opposite surface 
Corner notch within the hole zone was done by electrical discharge method (EDM). With wire diameter equal to $0,2 \mathrm{~mm}$, the EDM provides accuracy of $\pm 0,03 \mathrm{~mm}$. In the first case, the plastic deformation of the hole with a diameter of $d_{0}=8 \mathrm{~mm}$ is preceded by the procedure of notching and a fatigue crack initiation. Then, the specimen was subjected to cyclic loading at a constant load amplitude. Cold expansion degree was determined by the formula:

$$
i=\left(d_{1}-d_{\mathrm{o}}\right) / d_{o} \cdot 100 \%
$$

where $\boldsymbol{d}_{\mathrm{o}}, \boldsymbol{d}_{\mathbf{1}}$ - hole diameter before and after deformation.

\section{Table 1}

Technology of preparation of specimens with a cold expanded hole and a pre-crack for testing of fatigue crack growth

\begin{tabular}{|c|c|c|}
\hline $\begin{array}{c}\text { Cross section of the specimen side } \\
\text { with the preexisting crack at hole }\end{array}$ & \multirow{2}{*}{ Sequence of specimen preparation } \\
\hline \multicolumn{2}{|c|}{ Initial hole diameter, mm } & \\
\hline$d_{0}=8 \mathrm{~mm}$ & $d_{0}=7,76 \mathrm{~mm}$ & Corner notch (EDM) $0,5 \times 0,5 \mathrm{~mm}$ \\
\hline & & Corner pre-crack smaller than $1,25 \mathrm{~mm}$ \\
\hline & & Cold expansion, mandrel diameter $8 \mathrm{~mm}$ \\
\hline
\end{tabular}

The stress intensity factor range for the plate with a center through crack $2 a$ under tension was calculated by the formula [19]:

$$
\Delta K=\frac{\Delta P}{B} \sqrt{\frac{\pi \alpha}{2 W} \sec \frac{\pi \alpha}{2}}
$$

where $\alpha=2 a / W$; equation is true for $2 \alpha / W<0,95$; $W$ is width specimen.

The range of the applied force:

$$
\Delta P=P_{\max }-P_{\min }
$$

Stress ratio was calculated by the formula:

$$
R=K_{\min } / K_{\max },
$$

where $K_{\min }, K_{\max }$ are the minimum and maximum stress intensity factors correspondingly.

When the length $a$ of a fatigue crack growth through the entire thickness of the specimen $t$, it becomes a through-thickness crack.

For the specimen with an corner crack near the hole (Fig. $1 \mathrm{c}$ ) the SIF for the normal mode was found by Newman and Raju formula [20]. SIF for two symmetrical quarter-elliptical corner cracks near the hole (Fig. 3) was calculated by the formula [20]: 


$$
\Delta K=\Delta \sigma \sqrt{\pi \frac{a}{Q}} F_{c h}\left(\frac{a}{c_{1}}, \frac{a}{t}, \frac{r}{t}, \frac{r}{2 W}, \frac{c_{1}}{2 W}, \varphi\right)
$$

Formula (5) is true for $0,2 \leq a / c \leq 2 ; a / t<1 ; 0,5 \leq r / t \leq 2 ;(r+c) / b<0,5 ; 0 \leq \varphi \leq \pi / 2$.

For a sample with one quarter-elliptical corner crack near the hole SIF was obtained from the ratio [20]:

$$
\begin{gathered}
(K)_{\text {one crack }} \sqrt{\sqrt{\frac{\frac{4}{\pi}+\frac{a c}{2 t r}}{\pi}+\frac{a c}{t r}}(K)_{\text {two crack }}} \\
\Delta \sigma=\frac{\left(P_{\max }-P_{\min }\right)}{S}
\end{gathered}
$$

where $S$ is cross section area; $\Delta \sigma$ is tensile stress range; $2 W$ is specimen width; $r$ is hole radius; $\varphi$ is parametric angle of ellipse, deg; $Q$ is crack shape correction factor which is calculated by the formula:

$$
Q=1+1,464\left(\frac{c}{a}\right)^{1,65}
$$

Function $F_{c h}$, which is correction and includes crack geometry and size, plate and hole dimensions, is defined as [20]:

$$
F_{c h}=\left[M_{1}+M_{2}\left(\frac{a}{t}\right)^{2}+M_{3}\left(\frac{a}{t}\right)^{4}\right] g 1 g 2 g 3 g 4 F_{\phi} F_{w}
$$

For $a / c<1$ correction factor of crack front shape $Q$ is determined by the formula:

$$
Q=1+1,464\left(\frac{a}{c}\right)^{1,65}
$$

Parameters $M_{1}, M_{2}, M_{3}, g_{1}, g_{2}, g_{3}, g_{4}, f_{\phi}, f_{w}$ for $a / c<1$ are defined by the following equation [20]:

$$
\begin{gathered}
M_{1}=1,13-0,09\left(\frac{c}{a}\right), \\
M_{2}=-0,54+\left(\frac{0,89}{0,2+\frac{a}{c}}\right), \\
M_{3}=0,5-\frac{1}{0,65+\frac{a}{c}}+14\left(1-\frac{a}{c}\right)^{24}, \\
g_{1}=1+\left[0,1+0,35\left(\frac{a}{t}\right)^{2}\right](1-\sin \varphi)^{2},
\end{gathered}
$$




$$
\begin{gathered}
g 2=\frac{1+0,358 \lambda+1,425 \lambda^{2}-1,578 \lambda^{3}+2,156 \lambda^{4}}{1+0,13 \lambda^{2}}, \\
\lambda=\frac{1}{1+\frac{C}{R} \cos (\mu \varphi)}
\end{gathered}
$$

where $\mu=0,85$.

$$
\begin{gathered}
g_{3}=\left(1+0,04 \frac{c}{a}\right)\left[1+0,1(\cos \varphi)^{2}\right]\left[0,85+0,15\left(\frac{a}{t}\right)^{1 / 4}\right], \\
g_{4}=1-0,7\left(1-\frac{a}{t}\right)\left(\frac{a}{c}-0,2\right)\left(1-\frac{a}{c}\right) \\
f_{\phi}=\left[\left(\frac{a}{c}\right)^{2} \cos ^{2} \varphi+\sin ^{2} \varphi\right]^{1 / 4}, \\
f_{w}=\left[\sec \left(\frac{\pi r}{2 W}\right) \sec \left(\frac{\pi(2 r+n c)}{4(W-c)+2 n c}\right) \sqrt{\frac{a}{t}}\right]^{1 / 2},
\end{gathered}
$$

where $n=1$.

The mandrel with the diameter of $8^{+0,03} \mathrm{~mm}$ was manufactured of $40 \mathrm{X}$ steel and annealed to the hardness of 35-38 HRC (Fig. 2 a). For cold expansion hole process a 40X steel matrix was used which was annealed to the hardness of 35-38 HRC (Fig. 2 b). The mandrel speed was $0,1 \mathrm{~mm} / \mathrm{sec}$. Based on study, [21] such mandrel speed provides maximum efficiency of cold expansion, i.e. peak value of residual compressive stress.

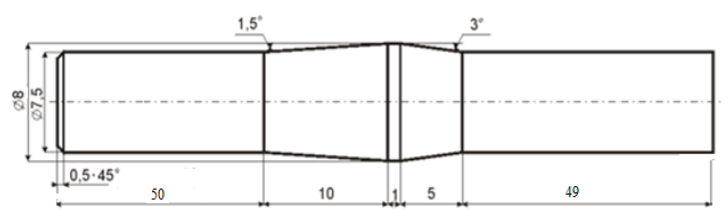

a)

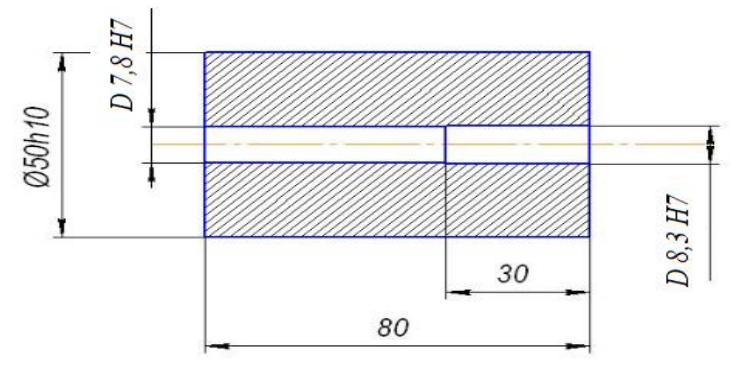

b)

Figure 2. Mandrel (a) and calibration matrix (b) for diameter hole $8 \mathrm{~mm}$

The process of cold expansion, pre-crack and fatigue crack growth test were performed on CTM-100 electrohydraulic machine, made by Antonov Design Bureau, with control system and BISS data selection (Fig. 3 a). Displacement measurement error was less than $1 \%$ of peak value of the set scale range. Before testing, areas of crack propagation surfaces were polished to a roughness of $R_{a}=0,05$. To ensure required accuracy of measuring the crack growth on the surface of the hole and flat surface of the specimen perpendicular to the direction of crack propagation marks were made in every $0,5 \mathrm{~mm}$. A crack initiated with the length of $0,5 \mathrm{~mm}$ from the notch under control load at $R=0,05$. Length of fatigue crack growth $c$ and $a$ were measured using binocular microscope MBC-10. 
The mandrel was fixed at the top clamp of the machine and the plate was mounted on a calibration matrix fixed coaxially with the mandrel on the lower movable clamp. (Fig. 3 b).

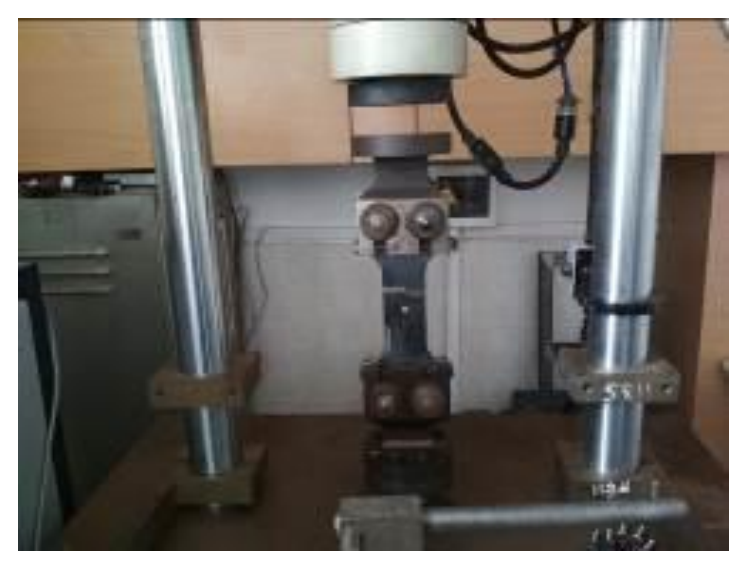

a)

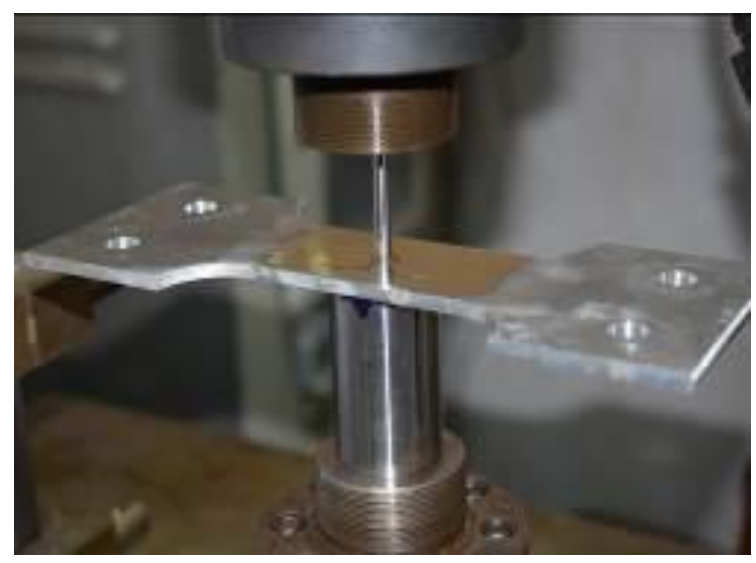

b)

Figure 3. Photo of mounting of the plate on the testing machine: $\mathrm{a}$ - fatigue crack growth testing; $\mathrm{b}$ - cold expansion process

According to the results obtained, with the speed of the mandrel equal to $0,1 \mathrm{~mm} / \mathrm{sec}$, the dependence of cold expansion force $P$ on the movement of mandrel $S$ through the hole was built. (Fig. 4).

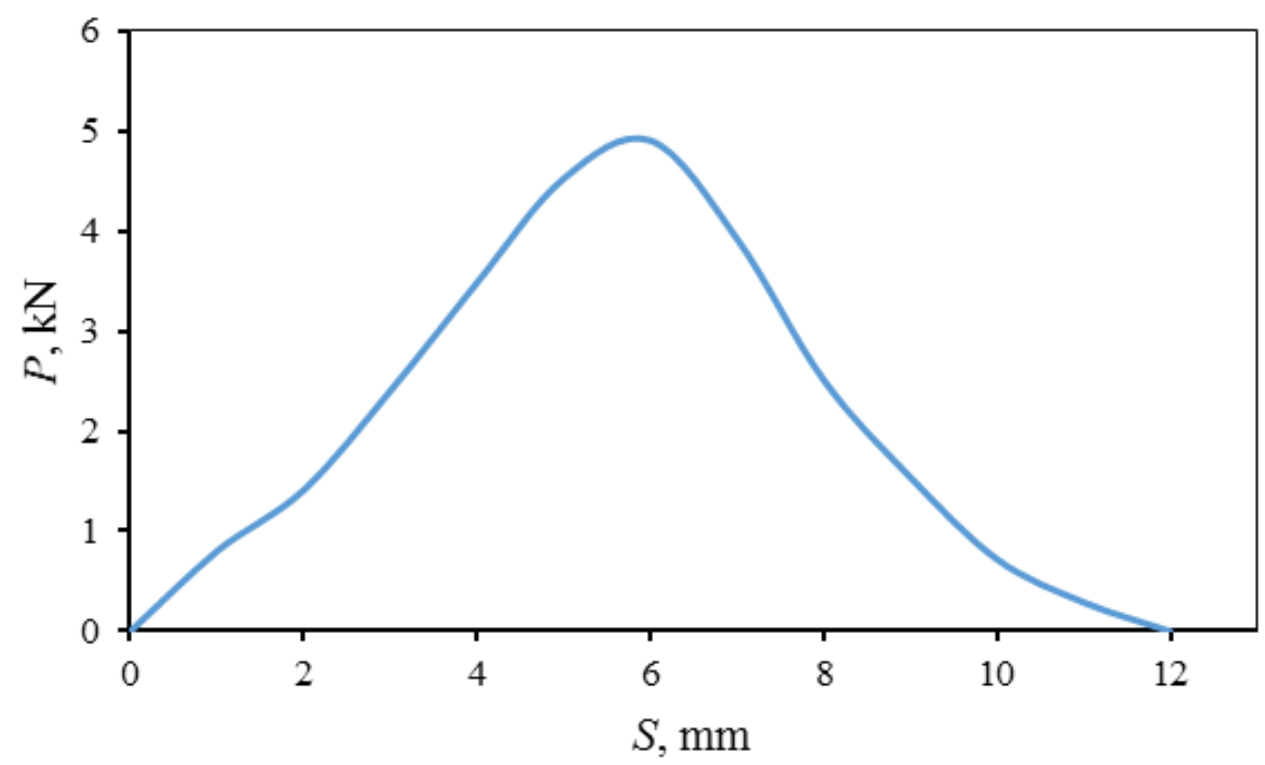

Figure 4. Dependence of force on the mandrel movement during cold expansion

Results and discussion. The test was performed with the constant stress range of 147 $\mathrm{MPa}$ at the asymmetry stress ratio $R=0,05$. The cycle form is sinusoidal, the loading frequency equals $10 \mathrm{~Hz}$. Figure 5 demonstrates crack propagation path (Fig. $5 \mathrm{a}, \mathrm{b}$ ) and fracture surfaces (Fig. 5 c, d) in the virgin (Fig. 5 a, c) and cold expanded specimen (Fig. 5 b, d). 


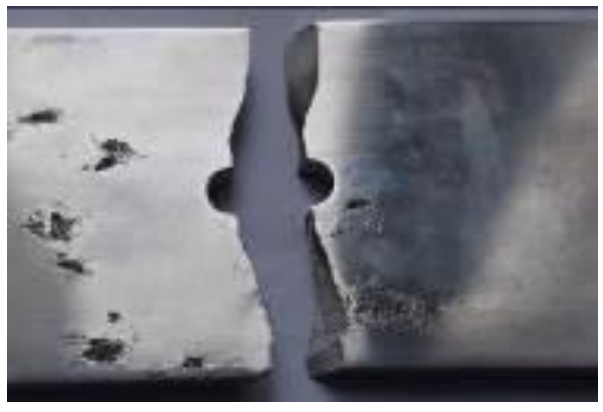

a)
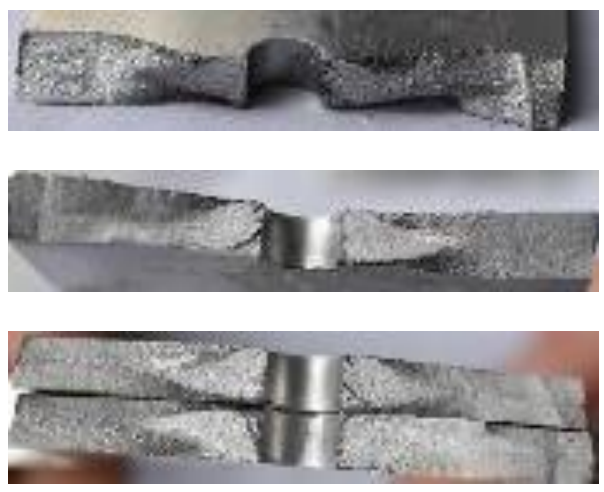

c)

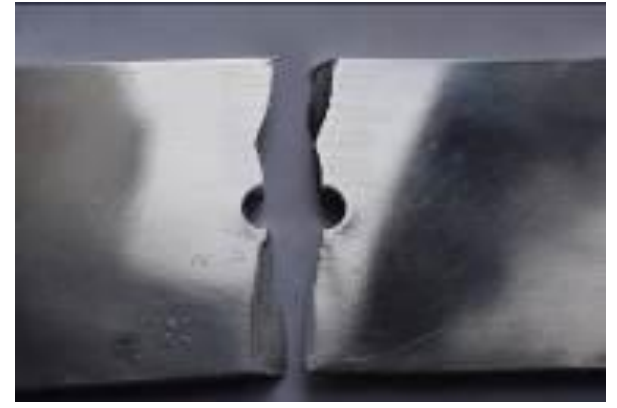

b)
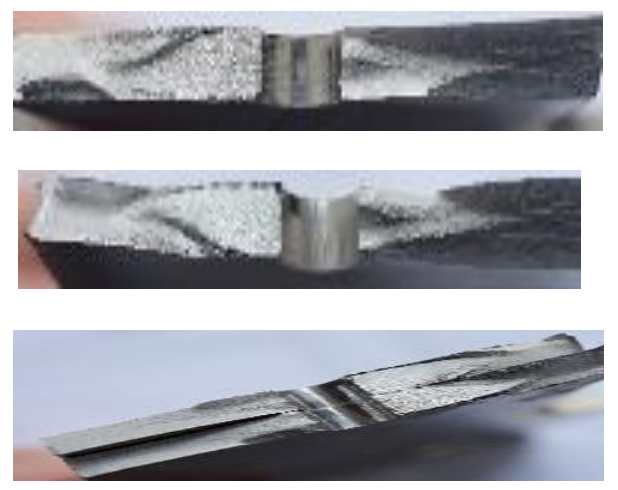

d)

Figure 5. Crack path growth $(a, b)$ and the fracture surface $(c, d)$ of the virgin specimen $(a, c)$ and with cold expansion degree $i=2,7 \%(\mathrm{~b}, \mathrm{~d})$

The pre-crack size in virgin and mandrelled plates are shown in Table 2. Crack growth retardation in the plate after cold expansion was equal to 53940 cycles, then its growth path came along the flat surface and through the thickness of the specimen.

Table 2

The pre-crack sizes and the number of cycles to retardation and to failure

\begin{tabular}{|c|c|c|c|c|c|c|}
\hline \multirow{2}{*}{$\begin{array}{c}\text { Initial hole } \\
\text { diameter, } \\
\text { mm }\end{array}$} & \multirow{2}{*}{$\begin{array}{l}\text { Hole diameter } \\
\text { after cold } \\
\text { expansion, } \\
\text { mm }\end{array}$} & \multirow{2}{*}{$\begin{array}{c}\text { Cold } \\
\text { expansion } \\
\text { degree, } \%\end{array}$} & \multicolumn{2}{|c|}{$\begin{array}{l}\text { Pre-crack size } \\
\text { mm }\end{array}$} & \multirow{2}{*}{$\begin{array}{l}\text { Number of } \\
\text { cycles to } \\
\text { failure }\end{array}$} & \multirow{2}{*}{$\begin{array}{l}\text { Number of } \\
\text { cycles to } \\
\text { retardation } \\
\text { crack growth }\end{array}$} \\
\hline & & & $c$ & $a$ & & \\
\hline 8 & - & - & $1,($ & 0,5 & 32245 & - \\
\hline 7,76 & 7,97 & 2,7 & 1,16 & 1,09 & 140817 & 53940 \\
\hline
\end{tabular}

SIF was calculated for crack front points at the angle of $\varphi=0^{\circ}$ on the flat surface and at the angle of $\varphi=90^{\circ}$ for cylindrical surface. SIF for one and two symmetrical quarter-elliptical cracks was found by equation (5), (6) and (5) correspondingly.

Dependence of crack front shape factor $a / c$ on the number of loading cycles of the virgin plate with initial hole diameter of $8 \mathrm{~mm}$ (Fig. 6 a) has three zones: descending, (I), related to crack retardation up to 3500 cycles; ascending (II) from $a / c=0,25$ to $a / c=0,86$ and constant one (III). For cold expanded specimen, one can observe similar regularity of change in the crack front shape from the number of loading cycles apart from zone (III) (Fig. 6 b). 


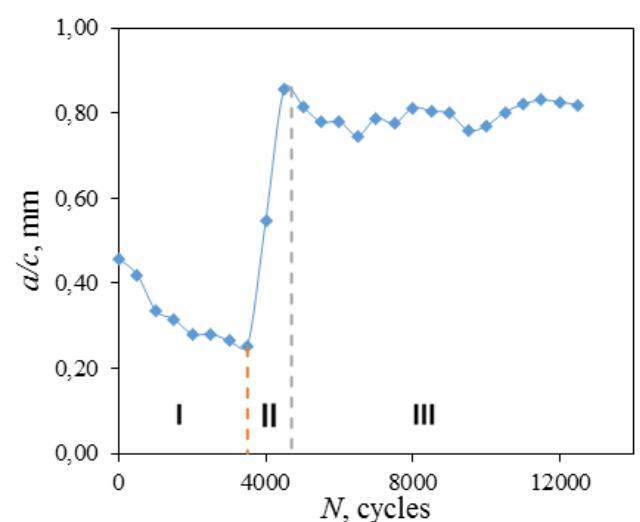

a)

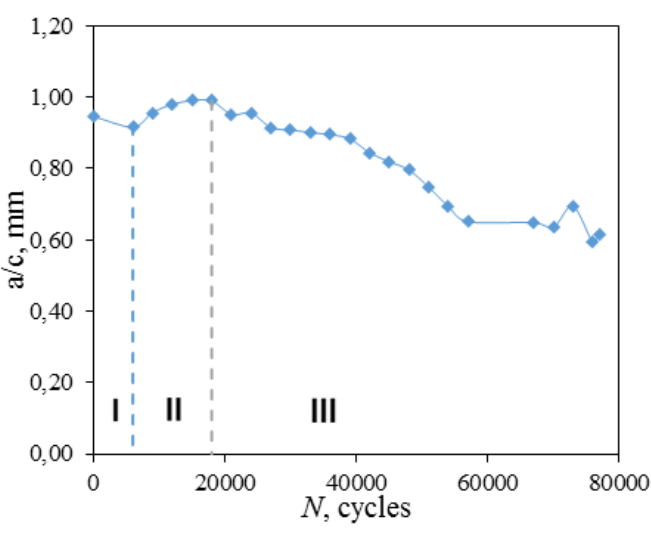

b)

Figure 6. Dependence of the crack front coefficient $a / c$ on the number of load cycles in the virgin plate (a) and with cold expansion degree $i=2,7 \%$ (b)

Dependencies of crack width $c$ and $a$ on number of cycles in virgin and mandrel plates are shown on Fig. $7 \mathrm{a}$ and Fig. $7 \mathrm{~b}$ relatively. After a pre-crack growth process the initial length $c$ was two times greater its perpendicular length $a$. The crack propagated on the plate surface, but no growth increment $a$ through the thickness within 3500 loading cycles. (Fig. 7 a). The further loading, the crack increased in its size $c$ and $a$. At the initial stage of cyclic loading of the plate after cold expansion $(N \leq 20000$ cycles) the crack lengths $a$ and $c$ have almost the same values. Further loading shows that the crack growth on the surface occurs faster than the crack propagation through the hole and if $a=t=6 \mathrm{~mm}$, then the crack length on the surface is $c=9,74 \mathrm{~mm}$ (Fig. $7 \mathrm{~b}$ ).

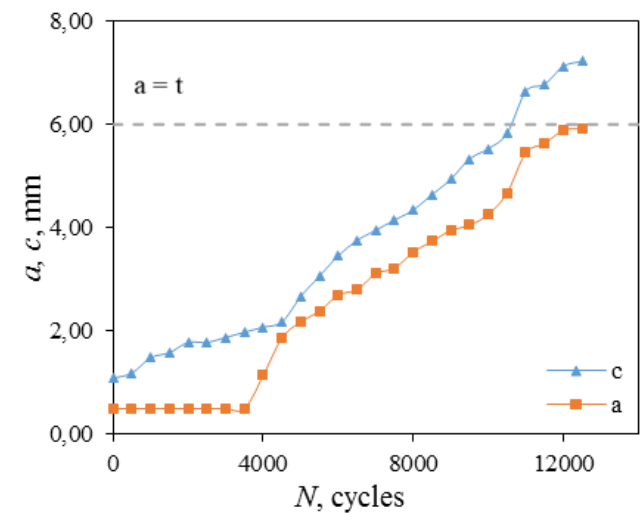

a)

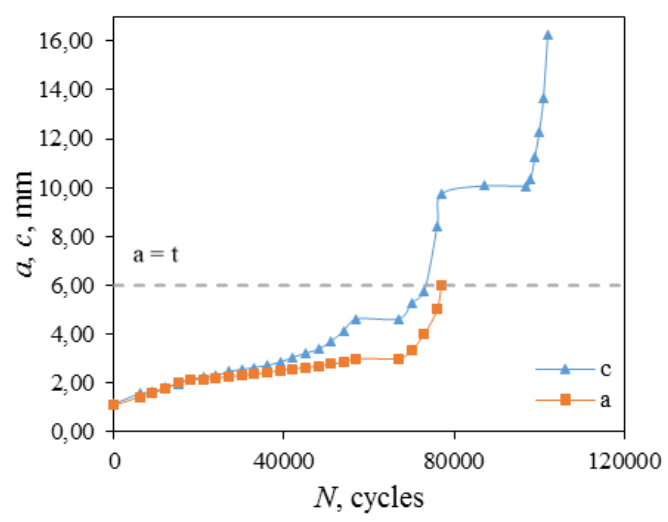

b)

Figure 7. Dependence of the crack size $a\left(\varphi=0^{\circ}\right)$ and $c\left(\varphi=90^{\circ}\right)$ on the number of load cycles in the virgin plate (a) and with cold expansion degree $i=2,7 \%$ (b)

Figure 8 shows the comparison of quarter-elliptical crack growth rate in the vicinity of the hole in directions $\varphi=0^{\circ}$ and $\varphi=90^{\circ}$ on SIF range. For the virgin plate (Fig. 8 a), with SIF being within the range from $9 \mathrm{MPa} \cdot \sqrt{\mathrm{m}}$ to $13 \mathrm{MPa} \cdot \sqrt{\mathrm{m}}$ the crack growth rate along the path of the straight hole exceeds the one $d c / d N$ being propagated on the flat surface. If SIF increases, the fatigue crack growth rate of $d c / d N$ and $d a / d N$ are within the compatible scatter band. If SIF increases $(\Delta K>16 \mathrm{MPa} \cdot \sqrt{\mathrm{m}})$, the fatigue crack growth rate in both directions is within the compatible scatter band. (Fig. 8 b). 


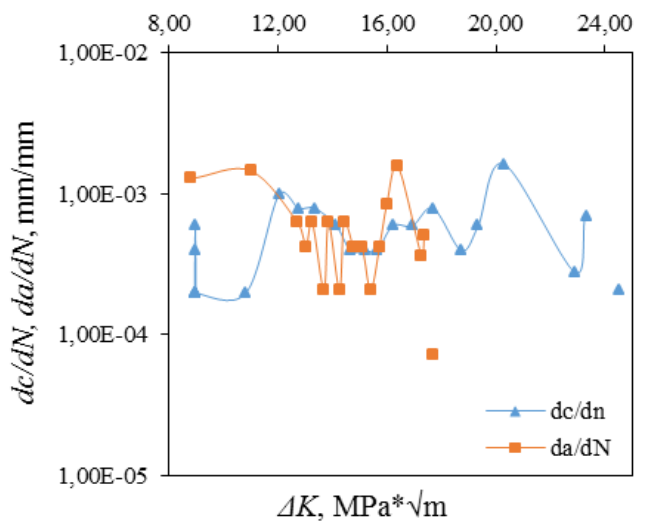

a)

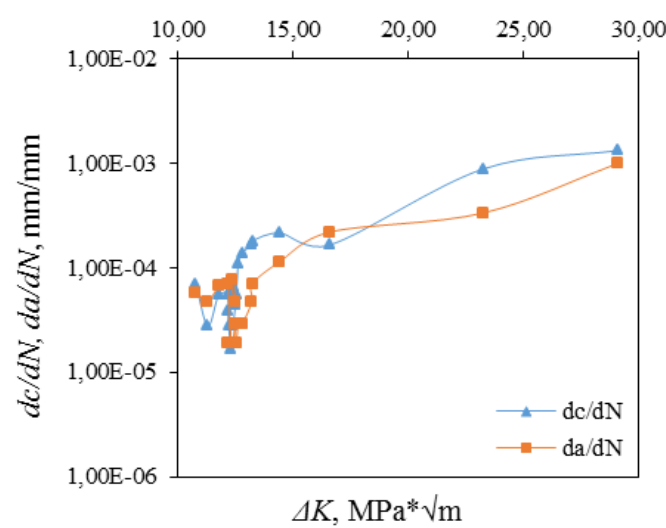

b)

Figure 8. Comparison of the fatigue crack growth rate $d c / d N\left(\varphi=0^{\circ}\right)$ and $d a / d N\left(\varphi=90^{\circ}\right)$ from the SIF range in the virgin plate (a) and with cold expansion degree $i=2,7 \%$ (b)

Crack front shape coefficient $a / c$ is smaller for the virgin plate (Fig. 9 a) with the crack length of $c<3 \mathrm{~mm}$ and greater at $c>4 \mathrm{~mm}$, if compared with the specimen after cold expansion. Fatigue crack propagation rate in the plate subjected to cold expansion of the holes significantly increases in comparison with virgin material with the following values: SIF $\Delta K<20 \mathrm{MPa} \cdot \sqrt{\mathrm{m}}$. With the increase in amplitude of SIF, fatigue crack growth rate, $d c / d N$ in virgin and cold expanded plate almost coincide. Comparative dependences of the crack growth rate $d a / d N$ on the SIF range in the virgin plate and the one after cold expansion of the hole with $i=2,7 \%$ (Fig. 9 b).

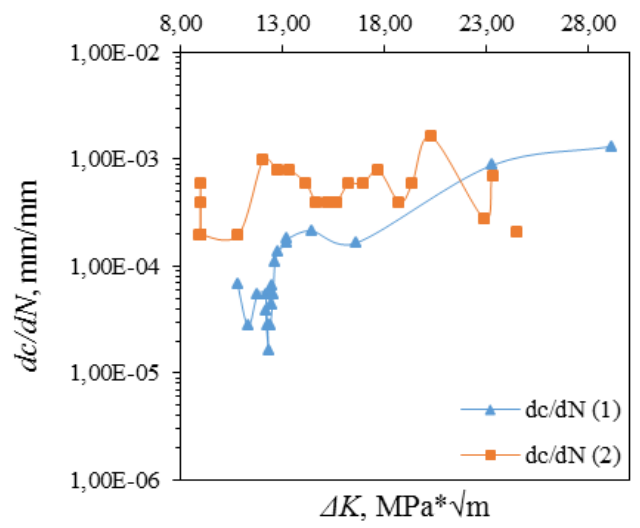

a)

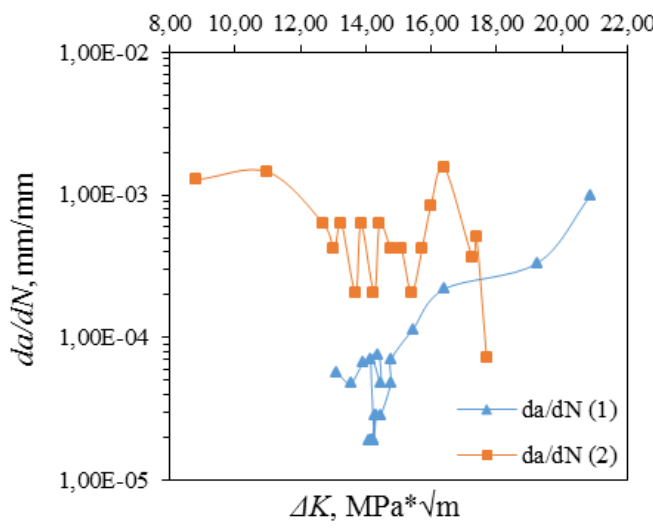

b)

Figure 9. Comparative dependences of the crack growth rate $d c / d N$ and $d a / d N$ on the amplitude of the SIF range in the direction $\varphi=0^{\circ}$ (a) and $\varphi=90^{\circ}$ (b) after cold expansion degree $i=2,7 \%$ (1) and in the virgin plate (2)

Figure10 illustrates comparative dependences of the fatigue crack lengths $a$ and $c$ in virgin and mandrel plates $(i=2,7 \%)$ on the number of load cycles for the angle $\varphi=0^{\circ} \mathrm{i}$ $\varphi=90^{\circ}$. Plastic hole deformation (cold expansion) with a pre-crack $c$ and strain of $i=2,7 \%$ significantly retards the crack propagation both on the plate flat surface and along generated hole (length $a$ ) if compared with the virgin plate. 


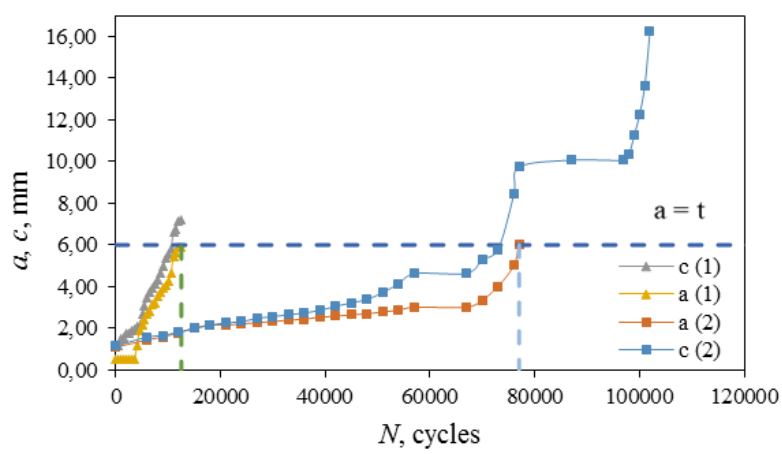

Figure 10. Dependences of the crack size $c\left(\varphi=0^{\circ}\right)$ and $a\left(\varphi=90^{\circ}\right)$ on the number of load cycles in the virgin plate (1) and with cold expansion degree of $i=2,7 \%$ (2)

Such a considerable effect of fatigue crack growth after cold expansion hole is caused by strengthening of material and development of residual compressive stresses within the vicinity of the hole. To other factors, which influence on the crack growth retardation, belong development of residual stresses and blunting crack front due to overloads at the cold expansion process.

\section{Conclusion}

1. The influence of cold expansion hole in D16chT aluminum alloy plates with preexisting quarter-elliptical crack onto fatigue crack growth was investigated.

2. The fatigue crack growth rate on the surface of the plate D16chT alloy after cold expansion hole with pre existing crack with degree of $2,7 \%$ is increased to $10-15$ times in comparison with the virgin plate if SIF $\Delta K<20 \mathrm{MPa} \sqrt{\mathrm{m}}$. The similar regularity of fatigue crack growth along the through hole was studied.

3. The residual lifetime of D16chT alloy plate after cold expansion hole degree 2,7\% with preexisting crack increases to three times to compare with the non-deformed plate. The residual lifetime corresponded to the number of cycles for the crack grow to the throughthickness hole. Thus, the effect of life enhancement is caused by cold-work strengthening of the material, residual compressive stresses within the vicinity of the hole and crack tip, as well as its blunting the crack front as a result of overloads during the cold expansion process.

\section{Reference}

1. Ball D., Lowry D. R. Experimental investigation on the effects of cold expansion of fastener holes. Fatigue Fract. Eng. Mater. Struct. Blackwell Publishing Ltd., 1998, Vol. 21. No 1. P. 17-34. https://doi.org/10.1046/j.1460-2695.1998.00430.x

2. Warner J. J., Clark P. N., Hoeppner D. W. Cold expansion effects on cracked fastener holes under constant amplitude and spectrum loading in the 2024-T351 aluminum alloy. Int. J. Fatigue. 2014, Vol. 68. P. 209216. https://doi.org/10.1016/j.ijfatigue.2014.05.002

3. Wang Y. Investigation on fatigue performance of cold expansion holes of 6061-T6 aluminum alloy. Int. J. Fatigue. 2017, Vol. 95. P. 216-228. https://doi.org/10.1016/j.ijfatigue.2016.10.030

4. Houghton S. J., Campbell S. K. Identifying the residual stress field developed by hole cold expansion using finite element analysis. Fatigue Fract. Eng. Mater. Struct. Blackwell Publ. Ltd. 2012, Vol. 35. No 1. P. 7483. https://doi.org/10.1111/j.1460-2695.2011.01616.x

5. Yasnii P., Glado S., Skochylyas V. Formation of residual stresses in plates with functional holes after mandrelling. Mater. Sci. 2015, Vol. 50. No 6. P. 877-881. https://doi.org/10.1007/s11003-015-9796-x

6. Gopalakrishna H., Narasimha Murthy H., Krishna M. Cold expansion of holes and resulting fatigue life enhancement and residual stresses in Al 2024 T3 alloy - An experimental study. Eng. Fail. Anal. 2010, Vol. 17. No 2. P. 361-368. https://doi.org/10.1016/j.engfailanal.2009.08.002

7. Elajrami M., Melouk H. Effect of double cold expansion on the fatigue life of rivet hole. Int. J. Mining, Metall. Mech. Eng. 2013, Vol. 1. No 2. P. 111-113.

8. Yordan T., Duncheva G. Device and tool for cold expansion of fastener holes: pat. US8915114 B2 USA. 2014, P. 1-6.

9. Pasta S., Mariotti G. Effect of residual stresses and their redistribution on the fatigue crack growth in coldworked holes. Int. Conf. CRACK PATHS. 2009. P. 895-902. 
10. Kennedy et al. US5265456A. Method of cold working holes using a shape memory alloy tool. 1992.

11. Yasniy P. V., Dyvdyk O. V., Yasniy V. P. "Instrument iz splavu z pam"yattyu formy dlya zmitsnennya otvoriv v plastynakh" Pat. 132422 Ukrayina MPK B24B 39/00; byul. No 4. 2019. [In Ukrainian].

12. Fu Y. Cold expansion technology of connection holes in aircraft structures: A review and prospect. Chinese J. Aeronaut. 2015, Vol. 28. No 4. P. 961-973. https://doi.org/10.1016/j.cja.2015.05.006

13. Elagrami M. Effect of double cold expansion on the fatigue life of rivet hole. Int. J. Mining, Metall. Mech. Eng. 2013, Vol. 1. No 2. P. 2320-4060.

14. Panaskar N. J., Sharma A. Combined Cold Expansion and Friction Stir Processing of Fastener Holes in Aluminum Alloy Al-2014-T6. Trans. Indian Inst. Met. 2017, Vol. 70. No 1. P. 107-114. https://doi.org/10.1007/s12666-016-0865-0

15. Simmons Gary G. Fatigue Enhancement of Undersized, Drilled Crack-Arrest Holes By Fatigue. Diss. degree Dr. Philos. thesis. Civil, Environ. Archit. Eng. Grad. Fac. Univ. Kansas. 213AD, 497 p.

16. Vallieres G., Duquesnay D. L. Fatigue life of cold-expanded fastener holes with interference - fit fasteners at short edge margins. Fatigue Fract. Eng. Mater. Struct. 2015, Vol. 38. No 5. P. 574-582. https://doi.org/10.1111/ffe.12257

17. Novikov A. Interrelation and kinetics of matersals fatigue damage under strain- and stress-control loading modes. Scientific Journal of TNTU (Tern.). 2017. Vol. 88. No 4. P. 35-48. https://doi.org/10.33108/visnyk_tntu2017.04.035

18. Pidgurskyi I. Analysis of stress intensity factors obtained with the fem for surface semielliptical cracks in the zones of structural stress concentrators. Scientific Journal of TNTU (Tern). 2018. Vol. 90. No 2. P. 92104. https://doi.org/10.33108/visnyk_tntu2018.02.092

19. ASTM E 647-00. E 647 - 00 Standard. Standard Test Method for Measurement of Fatigue Crack Growth Rates. 2001. Vol. 3. P. 43.

20. Newman J. C., Raju I. S. Stress-intensity factor equations for cracks in three-dimensional finite bodies subjected to tension and bending loads. Hampton: 1984.

21. Tymoshenko A., Pymanov V., Babak A., Korobko E. Yssledovanye protsessa dornovanyya otverstyy v lystovykh zahotovkakh yz alyumynyevoho splava D16chT. Visnyk NTUU "KPI". Mashynobuduvannya zbirnyk naukovykh prats'. 2015, Vol. 75. No 3. P. 144-150. [In Ukrainian].

\section{Список використаної літератури}

1. Ball D., Lowry D. R. Experimental investigation on the effects of cold expansion of fastener holes. Fatigue Fract. Eng. Mater. Struct. Blackwell Publishing Ltd. 1998. № 1 (21). P. 17-34. https://doi.org/10.1046/j.1460-2695.1998.00430.x

2. Warner J. J., Clark P. N., Hoeppner D. W. Cold expansion effects on cracked fastener holes under constant amplitude and spectrum loading in the 2024-T351 aluminum alloy. Int. J. Fatigue. 2014. Vol. 68. P. 209216. https://doi.org/10.1016/j.ijfatigue.2014.05.002

3. Wang Y. Investigation on fatigue performance of cold expansion holes of 6061-T6 aluminum alloy. Int. J. Fatigue. 2017. Vol. 95. P. 216-228. https://doi.org/10.1016/j.ijfatigue.2016.10.030

4. Houghton S. J., Campbell S. K. Identifying the residual stress field developed by hole cold expansion using finite element analysis. Fatigue Fract. Eng. Mater. Struct. Blackwell Publ. Ltd. 2012. № 1 (35). P. 74-83. https://doi.org/10.1111/j.1460-2695.2011.01616.x

5. Yasnii P., Glado S., Skochylyas V. Formation of residual stresses in plates with functional holes after mandrelling. Mater. Sci. 2015. № 6 (50). P. 877-881. https://doi.org/10.1007/s11003-015-9796-x

6. Gopalakrishna H., Narasimha Murthy H., Krishna M. Cold expansion of holes and resulting fatigue life enhancement and residual stresses in Al 2024 T3 alloy - An experimental study. Eng. Fail. Anal. 2010. № 2 (17). P. 361-368. https://doi.org/10.1016/j.engfailanal.2009.08.002

7. Elajrami M., Melouk H. Effect of double cold expansion on the fatigue life of rivet hole. Int. J. Mining, Metall. Mech. Eng. 2013. № 2 (1). P. 111-113.

8. Yordan T., Duncheva G. Device and tool for cold expansion of fastener holes: pat. US8915114 B2 USA. 2014. P. 1-6.

9. Pasta S., Mariotti G. Effect of residual stresses and their redistribution on the fatigue crack growth in coldworked holes. Int. Conf. CRACK PATHS (CP 2009). 2009. P. 895-902.

10. Kennedy et al. US5265456A. Method of cold working holes using a shape memory alloy tool. 1992.

11. Ясній П. В., Дивдик О. В., Ясній В. П. «Інструмент із сплаву з пам'яттю форми для зміцнення отворів в пластинах»: пат. 132422 Україна МПК В24В 39/00, Бюл. № 4. 2019.

12. Fu Y. Cold expansion technology of connection holes in aircraft structures: A review and prospect. Chinese J. Aeronaut. 2015. № 4 (28). P. 961-973. https://doi.org/10.1016/j.cja.2015.05.006

13. Elagrami M. Effect of double cold expansion on the fatigue life of rivet hole. Int. J. Mining, Metall. Mech. Eng. 2013. № 2 (1). P. 2320-4060.

14. Panaskar N. J., Sharma A. Combined Cold Expansion and Friction Stir Processing of Fastener Holes in Aluminum Alloy Al-2014-T6. Trans. Indian Inst. Met. 2017. № 1 (70). P. 107-114. https://doi.org/10.1007/s12666-016-0865-0 
15. Simmons Gary G. Fatigue Enhancement of Undersized, Drilled Crack-Arrest Holes By Fatigue. Diss. degree Dr. Philos. thesis. Civil, Environ. Archit. Eng. Grad. Fac. Univ. Kansas. 213AD. 497 p.

16. Vallieres G., Duquesnay D. L. Fatigue life of cold-expanded fastener holes with interference - fit fasteners at short edge margins. Fatigue Fract. Eng. Mater. Struct. 2015. № 5 (38). P. 574-582. https://doi.org/10.1111/ffe. 12257

17. Novikov A. Interrelation and kinetics of matersals fatigue damage under strain- and stress-control loading modes. Scientific Journal of TNTU. 2017. № 4 (88). P. 35-48. https://doi.org/10.33108/visnyk_tntu2017.04.035

18. Pidgurskyi I. Analysis of stress intensity factors obtained with the fem for surface semielliptical cracks in the zones of structural stress concentrators. Scientific Journal of TNTU. 2018. № 2 (90). P. 92-104. https://doi.org/10.33108/visnyk_tntu2018.02.092

19. ASTM E 647-00. E 647 - 00 Standard. Standard Test Method for Measurement of Fatigue Crack Growth Rates. 2001. Vol. 3. P. 43.

20. Newman J. C., Raju I. S. Stress-intensity factor equations for cracks in three-dimensional finite bodies subjected to tension and bending loads. Hampton: 1984.

21. Тимошенко А., Пиманов В., Бабак А., Коробко Е. Исследование процесса дорнования отверстий в листовых заготовках из алюминиевого сплава Д16Чт. Вісник НТУУ «КПІ». Машинобудування. Збірник наукових праць. 2015. № 3 (75). С. 144-150.

\title{
УДК 539.3
}

\section{РОЗВИТОК ВТОМНОЇ ТРІЩИНИ В АЛЮМІНІЕВОМУ СПЛАВІ ПІСЛЯ ХОЛОДНОГО ЗМІЦЕННЯ ОТВОРУ 3 ПОПЕРЕДНІМ ДЕФЕКТОМ}

\author{
Петро Ясній ${ }^{1}$; Олександр Дивдик ${ }^{1}$; Олександр Семенець²; Володимир \\ Ясній ${ }^{1}$; Андрій Антонов ${ }^{1}$
${ }^{1}$ Тернопільський національний технічний університет імені Івана Пулюя, Тернопіль, Україна ${ }^{2}$ Держсвне підприємство «Антонов», Київ, Україна

\begin{abstract}
Резюме. Досліджували втомну довговічність силових конструктивних елементів 3 експлуатаційними пошкодженнями в околі кріпильних отворів. Виявлено основні закономірності впливу дорнування отворів у пластинах із алюмінієвого сплаву Д1бчТ із попереднім втомним пошкодженням на кінетику росту втомних тріщин. Для дослідження було відібрано плоскі зразки шириною 60 мм і товщиною 6 мм з алюмінієвого сплаву Д16чТ з иентральним отвором. Втомні пошкодження досліджували з кутовою четвертьеліптичною втомною тріщиною, яку ініціювали з кутового одностороннього надрізу 0,5 $x$ 0,5 мм, опісля вирощували втомну тріщину довжиною 1,25 мм. Для дорнованого зразка для реалізаџії процесу поверхневого зміџнення відібрано дорн, який виготовляли зі сталі марки 40Х та загартовували до твердості 35-38 HRC. Швидкість переміщення дорна через отвір пластини дорівнювала 0,1 мм/сек. За розрахункову кінцеву довжину тріщини приймали значення, щчо дорівнювало товщині пластини, тобто фіксували момент, коли трішина ставала наскрізною. Швидкість РВТ на поверхні пластини зі сплаву Д1бчТ після дорнування отвору з натягом доорнування $i=2,7 \%$ збільшується в 10-15 разів порівняно з недеформованим зразком при значеннях розмаху коефіиієнта інтенсивності $\Delta K<20$ МПа $\sqrt{ }_{\text {}}$. Подібний характер впливу дорнування отворів на діаграму втомного руйнування зберігається й при поширенні тріщини вздовж твірної отвору. Дорнування отворів за відносного розширення $i=2,7 \%$ з попередніми втомними пошкодженнями значно підвищує залишкову довговічність пластини зі сплаву Д1бчТ. Найбільший ефект дорнування на залишкову довговічність проявлясться при початковому значенні довжини тріщини $a_{0}=1$ мм. Вказаний ефект підвищення довговічності спричинений деформаційним зміџненням матеріалу й створенням залишкових стискувальних напружень в околі отвору, а також притупленням і створенням залишкових стискувальних напружень у вістрі тріщини вздовж ї̈ фронту внаслідок перевантажень, які виникають при дорнуванні.

Ключові слова: холодне зміцнення отвору, попередньо вирощена тріщина, коефіцієнт інтенсивності напружень, залишкова довговічність, пластина з отвором, розвиток втомної тріщини, алюмінієвий сплав.
\end{abstract}

